MACROECONOMIC POLICY AND COLLECTIVE ACTION

\author{
by \\ David Colander
}

June 2008

MIDDLEBURY COLLEGE ECONOMICS DISCUSSION PAPER NO. 03-32

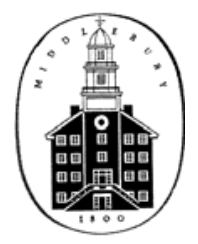

DEPARTMENT OF ECONOMICS

MIDDLEBURY COLLEGE

MIDDLEBURY, VERMONT 05753

http://www.middlebury.edu/ econ 


\section{MACROECONOMIC POLICY AND COLLECTIVE ACTION}

An individual cannot by saving more protect himself from the consequences of inflation if others do not follow his example: just as he cannot protect himself from accidents by obeying the rule of the road if others disregard it. We have here the perfect opportunity for social action, where everyone can be protected by making a certain rule of behavior universal. Keynes (1940)

In his posthumously published book, Power and Prosperity (2000), Mancur Olson returned to his long concern with why some countries are rich and others poor, and pushed his analysis a bit further. As seen from his early work, The Logic of Collective Action (1965), he focused on the ability of small groups to come together to obtain special-interest benefits and the failure of government to provide genuine public goods. As in his Presidential address to the Eastern Economic Association (1995), he described the relative merits of stationary bandits that have fairly encompassing interests, and roving bandits that "take and run." He then points out that small-scale market activity flourishes everywhere; it is the effectiveness of large-scale economic activity that determines whether an economy is prosperous or not.

Effective large-scale economic activity requires, according to Olson, that there are powerful political interests that focus on the overall gains to society--what he called in another context "market-augmenting government." It is these "encompassing interests" in a democratic society that assure that complex institutions can arise and produce effectively. These "encompassing interests" also fight against the tendency of narrow special interests to obtain special benefits.

Our argument in this paper is that macro policy can be usefully conceived of within a general Olsonian framework emphasizing the fight between special interests and encompassing interests. The policy question is how to encourage "encompassing interests" in a society to reign in the many special interests. There are many ways to do this, and, as Olson emphasized in his Power and Prosperity, one important way is the establishment of secure property rights and their boundaries to the exercise of power. We argue that thinking of macro policy as the development of "property rights rules" establishing "encompassing interests" in variables that affect macroeconomic outcomes provides useful insight into macro policy debates.

\section{Macroeconomic Externalities and Coordination Failures}

In the past two decades a body of work has developed that describes macroeconomic microfoundations with Keynesian properties. This approach is often called "New Keynesian" (Phelps 1985, Colander 1986, Romer 2001). Like New Classical or Real Business Cycle work, New Keynesians have adopted a dynamic general equilibrium modeling approach. The key elements include: (1) a general equilibrium framework; (2) analysis of the aggregate economy from a microeconomic perspective with rational maximizing agents; (3) a form of incomplete markets or an externality that lead to Keynesian properties. ${ }^{1}$ We refer to this approach as "New Keynesian” while agreeing that many authors in the Real Business Cycle tradition are doing

\footnotetext{
${ }^{1}$.David Romer's (2001) textbook has an up-to-date general review, and continues to use the term "New Keynesian" in a fashion similar to ours.
} 
similar work.

Most New Keynesian research has focused on particular sub-areas such as the labor or credit market, showing how small changes from the market-clearing assumption changed the stylized properties and policy conclusions from full-employment general equilibrium to Keynesian. ${ }^{2}$ One branch of that work, the coordination failure branch, such as seen in the work of Cooper and John (1988), is highly compatible with Olson's encompassing interest approach. ${ }^{3}$ This literature shows how coordination failures can lead to less than optimal macroeconomic outcomes. ${ }^{4}$

This coordination failure approach structures the macroeconomic problem as one of the individual following his or her own self-interest against the collective good, which may be to have less fluctuation in output than we currently have, a higher level of output, or less inflation than would exist in the existing market structure. Each of these problems can be seen as resulting from individuals following their own self-interest and not taking the broader encompassing interest into account. Thus, for example, when individuals respond more quickly to opportunities to raise their price than they do to lower their price, the result is an unsustainable rise in the price level, which would blow up if it were not anchored. Under current policy rules, in which the money supply is required to maintain a price level anchor, this requires markets, on average, to be kept in a position of excess supply, to the detriment of the encompassing interest. By creating property rights in prices, one can force individuals to take into account any affect their actions have on the aggregate price level, and thereby guide individuals to work for the encompassing interest even as they follow their specific interest.

As suggested in the introductory quote, which is from Keynes’ How to Pay for the War (1940), this coordination failure approach to macro policy has Keynesian roots. It sees the underlying cause of the macro problem as the existence of a macroeconomic externality, in which individual decisions do not lead to desirable results for the entire society. It can also be seen in the work of Baumol (1950) and Lerner (1960), but it disappeared during the golden years of neo-Keynesian macroeconomics, the 1960s, when it was just assumed that active monetary and fiscal policies were needed to stabilize the economy, without any micro foundation for these policies. By the 1970s, the rise of inflation and continued high unemployment led to a breakdown of the neo-Keynesian synthesis, leading theorists to explore alternative approaches.

\footnotetext{
${ }^{2}$ Akerlof and Yellen (1985), Azariadis (1981), Azariadis and Smith (1998), Greenwald and Stiglitz (1993), Phelps and Taylor (1977), Phelps (1985), Stiglitz (1986) and Woodford (1998, 1991) are in this category.

${ }^{3}$ Prominent examples are in Bryant (1982), Christiano and Eichenbaum (1992), Cooper and John (1988), and Cooper (1999). Romer (2001, chapter 4) makes this model the centerpiece of his description of macroeconomic complementarities.

${ }^{4}$ Considerable work has been done to obtain empirical evidence on macroeconomic coordination failures, which also go under the name of strategic complementarities. Bils and Klenow (1998) show that models of cyclical utilization do perform better in explaining consumer sales than several real business cycle approaches. Cooper and Haltiwanger (1993) provide evidence of a specific macroeconomic complementarity in automobile sales in the interwar period, while Cooper and Haltiwanger (1996) find evidence of co-movements in output consistent with macroeconomic complementarities. Levine and Zervos (1998) find that developed stock markets and banks increase growth and productivity, holding constant other factors, in a large sample of countries; these are means of improving coordination. Rotemberg and Woodford (1995) show that "stylized" empirical results fit macroeconomic complementarities well in dynamic general equilibrium growth models, in contrast to traditional real business cycle approaches.
}

Comment [COMMENT1]:

Unclear terminology 
These included the new microeconomic foundations and rational expectations theories, which undercut the neo-Keynesian model and required a microeconomic rational for Keynesian-type policies. The coordination failure approach provided the microeconomic rationality in a way that nicely fits Olson's general framework.

To demonstrate that relationship this paper relates the general idea of macroeconomic externality models found in strategic complementarities to Olson's ideas, arguing that his general approach fits not only micro issues, but macro issues too. In doing so it provides an organizing structure for thinking about macro policy within an collective interest framework: Given a macroeconomic externality, the policy problem from a collective interest framework is to find a method of internalizing the externality that provides greater gains than costs.

Once macro policy is placed within this broad encompassing interest framework, one we can move on to the real policy questions of determining the costs, administrative and other, including the costs of errors, of each specific policy, and of determining whether these costs are less than the benefits. By placing macro policy within Olson's framework one sees that economists differ on macro policy far more because of different estimates of these costs and far less because of differences in theory.

\section{A System of Market Rights in Macroeconomic Variables}

If negotiations over macroeconomic variables were cheap it would be relatively easy to develop institutions to guide specific interests toward encompassing interests. One could easily allow interagent negotiation, and, following Coase's argument, arrive at an acceptable solution. But negotiations are not cheap; they have very high transactions costs, since the effects are widespread and small, although in the aggregate they can be substantial. The problem facing encompassing interests is to design institutions to force individuals to undertake actions that lead to desirable macroeconomic results.

Designing those institutions presents into what might be called the Olsonian trap. Even though one knows that these are problems where the encompassing interest is great, in those negotiations about the design of the program special interests will have incentive to prevent the encompassing interests from winning, and to design the program to their benefit. For an economy to succeed, it must design enforceable rules, which limit special narrow interests and direct individuals toward an encompassing interest, but those rules must be created by the special interests that will be limited. The need is to pit one special interest against another and to maintain as much transparency in the negotiations as possible in establishment of property rights, which then become embodied into the institutions of the economy.

The role of government in guiding the development of such property rights is becoming more and more accepted in normal microeconomic examples. for example, air pollution rights are one an example--one that haves developed very effectively during the past decade. Each firm is allowed to pollute at specific levels. If a firm wishes to generate more pollution, rights must be purchased from other firms, which reduce their pollution. The price of the rights varies with supply and demand. By controlling the overall supply of pollution rights the government can, in effect, control the market price. Such systems have worked quite effectively in the Midwest and in Southern California (Schmalensee et al. 1998). 
However in macroeconomic variables, it is still misunderstood and seen as somewhat strange. These are seen as somehow more esoteric because macro policy has seldom been thought of in this way. However, what matters for policy is not how unusual they are, but how easily they are made into property, and for some types of these variables, such as inflation, the problems that exist are less difficult than in air or water rights because the dimensionality of what is being controlled is less.

As with a pollution externality, for a market to solve the macroeconomic externality problem, two basic issues must be resolved.: (1) The rights must be defined in some measurable way.; (2) The quantity of available rights must be fixed by the government (by law or regulation). Just as the overall level of permitted pollution must first be established by the government, for macroeconomic externalities the output objective must be identified. ${ }^{5}$

It is important to point out the different incentives of private actors under the two legal systems. Consider the market for pollution. Under a system of market rights to pollution, each firm defends politically its fixed amount of pollution rights and opposes politically every other firm's efforts to expand its rights, or to cheat on those rights. If other firms expand their rights, this reduces the market value of each firm's rights. The same issue exists with inflation. Under a system of market rights to inflation, each firm defends politically its fixed amount of rights to inflation, and opposes politically ever other firm's effort to expand on those rights. Thus, just like stockholders' shares, there is a political equilibrium maintaining the fixed quantity and assuring that the rights are maintained.

Before the market in pollution rights, firms individually had incentives to lobby for the legal right to expand their own pollution. These were "stationary bandits", in that everyone saw the harm they were doing, and could impose some costs on them. Also, each polluter saw benefits from cheating without being caught---(the "midnight pollution”). Similarly with inflation; firms lobby hard for their right to raise their price, but also lobby hard for the Fed to hold down inflation, which means limiting other firms from raising price. the reality is that to solve externality problems, we need both an economically efficient result, and a political balance of forces that will maintain the economically efficient result are needed. Market-based systems with enforceable property rights do the job can fulfill this requirement.

Of course, setting them up presents serious political problems and significant administrative costs. The desirability of this policy depends on whether the benefit from internalizing the externality outweighs the administrative costs of a system that is politically sustainable. Whether it is worthwhile to establish such policies depends on the current institutional structure. For example, countries that already measure firms' revenues in the form of a tax on value added, have much of the administrative machinery already in place, and will find it much easier to establish such policies than other countries.

\section{Markets Macroeconomic Variables}

\footnotetext{
${ }^{5}$ Chari and Jones (1988) show that markets in pure public goods, even when fully defined, are unlikely to operate well. The alternative approach, which we follow, is for a government to determine the size of the external effect and from it the socially optimal level of the pure public good. The rights established in the activity are for this amount. These rights are then valuable private goods to the firms, just as pollution rights are valuable private rights.
}

Comment [COMMENT2]:

Only pollution is considered here

Comment [COMMENT3]:
Reference the bandit
terminology from Olson
$(1993)$


There are a variety of macro variables that could be seen as output fluctuations, in which real output fluctuates more than desired, and inflation, which destroys the usefulness of money as a medium of exchange and thus reduces the trading efficiency of the economy.

that one could specify; the two standard ones One of the major problems in Thus far the external effect has been described without distinguishing between real and nominal revenue. But firms care about real revenue; it is other firms' real output that is fundamental to the aggregate demand externality. Yet macroeconomists have shown that firms often cannot distinguish real and nominal outputs. ${ }^{6}$ And other firms' decisions to increase output also tend to change the price level. If firms know their own demands the demands for their own products, but not the price level, the external effect is in others' nominal demand. But this includes now, along with an aggregate real demand externality, an aggregate price-level externality. ${ }^{7}$ If the price level should optimally remain constant, then firms' price-changing decisions, which affect the price level, create an external effect. ${ }^{8}$ For example, Taylor (1988) and Cooper (1988) describe price and wage setting coordination problems in which shocks generate a price-level externality. Beaudry et al. (2001) provide empirical evidence that price-level instability drastically reduces investment.

This leads to the possibility that in the short run there are two external effects upon firms. The first is aggregate nominal demand, so that nominal revenue of other firms is a positive external effect. The second is the price level, so that the aggregate of P's of other firms weighted by their quantities is a negative external effect, The first externality is the revenue externality solved by the market in aggregate revenue; the second externality is the "price-level change" externality which must be solved by a second market.

The price-level change externality has been discussed in the literature on Market Anti-inflation Plans (MAP) (see, for instance, Lerner and Colander (1980)). These proposals recommend the creation of a market in the right to change value added input prices. If a firm wishes to raise an input price, the right must be purchased from another firm that is lowering its input price. The MAP market keeps the price level constant in terms of "original" quantities.

output to rise, the price-level rule reduces the level of the output externality. MAP reduces the externality due to the firm's "monopoly" power--it acts as an economy-wide Ramsey pricing rule to reduce monopoly power.

The market in rights to raise prices is different than markets in pollution, because with the policy goal is not to reduce the price level, but instead to reduce either increases of decreases of the price level. Therefore the market in rights to change prices is symmetric, and raising price could have a positive or a negative price. Thus, if there is deflationary pressure in the economy, firms wanting to lower their prices would have to buy the right from firms wishing to raise their

\footnotetext{
${ }^{6}$ This is the New Classicals' "signal processing" concern (see Marcet and Sargent 1989, Sargent 1991).

${ }^{7}$ This externality may be due to search costs for price-level information, "menu" changing costs, costs of adjusting long-term contracts, or monopoly forces aggregate output lower (Colander 1992). In our static framework, the externality is a proxy for the costs due to inflation.

${ }^{8}$ Okun (1981, Ch. 7) concludes that the optimal inflation rate is "very low--close to zero," after discussing these various costs. Taylor (1993) proposes a policy that is widely accepted, of minimizing both inflation and low-output (huh?). But only such scholars as Meltzer and Svensson tend to favor a permanent "anchor" of price-level stability.
}

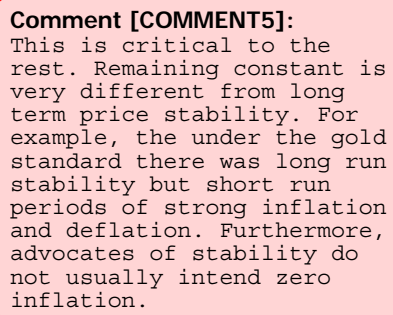


prices by an offsetting amount. We have discussed the technicalities of such markets in other papers (Lerner and colander, colander, .) and will not go through them here, other than to note that all supporters have the control variable to be value added per unit input, not direct control of output prices for both theoretical and practical reasons. also, it will be operative only for firms above a certain size, since if they hold their prices down, smaller firms will be forced to hold their prices down to be able to compete.

the administrative costs are substantial, but the gains are also substantial. first, the administrative costs are only large to the degree that there is significant price. If there is little inflationary pressure, the price of raising price will be close to zero, and firms will not be overly concerned with it. the existence of the market in this case still has the advantage of providing a direct measure of inflationary pressure in the economy, which the Fed can use to guide macro policy. If it sees a rise in price, it knows to reduce the money supply to offset it. Thus, coordination becomes much easier.

Practically implementing any such policy can be very difficult. Nevertheless, we believe that politically, focusing separately on the price-level and output externalities may have advantages. Stable prices are a politically potent value among the public and also among bondholders. Economists have also argued effectively that stable prices, guaranteed over the long run, are an important value. So there is both a political and economic constituency for stable prices. However, while it is well-known that there are populist "roving bandits" who will provide temporary output increases, the optimal level of output is much harder to define, and there is no real constituency against too-high output. This was shown in the mid-1990s, when output rose above the accepted full-employment level. While the final result may not have been disastrous (despite a bubble), it is clear that there was no strong political constituency for holding output steady. Thus, a structure that would assure stable output levels is not yet so evident.

\section{Considering Alternative Policies and their Costs}

The Federal Reserve system, which creates and enforces monetary policy in the U.S., is enjoined by law to promote growth, eliminate inflation, and increase employment, all at once. To achieve these goals, it has exactly one tool: It can raise or lower the interest rate that financial institutions pay when the borrow from each other overnight. It’s hard to hit three targets with one bullet... (Martin Mayer 2001)

Just as markets have costs, these policies have costs that must be evaluated. Markets in externalities have administrative and "divergence-from-optimality" costs. In addition, we must avoid Demsetz' "nirvana” fallacy, and be sure that any market-related policy is incentivecompatible, and so will be supported politically. This section discusses the two types of cost in order, examining their relative size for markets in externalities and for traditional fiscal and monetary policy. Then it discusses the various ways in which market-based policies may reduce the incentives for "bandits" to take advantage of the policy. ${ }^{9}$ We begin with a broad discussion of how traditional fiscal and monetary policy can be viewed in our macroeconomic externality framework. We believe that the underlying problem can also be viewed as an information problem: "Who should increase output?" in a recession. Monetary and fiscal policies are quite
Comment [COMMENT6]:

This section is far too long. We don't need details regarding problems in monetary and fiscal policy which are well known. This should be greatly condensed.

\footnotetext{
${ }^{9}$ See Grossman and Helpman (2001), as well as Olson (1995).
} 
arbitrary methods of "solving" the problem, and in an ever-changing economy the information problem may be too hard to solve effectively. In addition, such policies are often used, particularly in developing and transition countries, to build short-term political support at the expense of long-run stability. Therefore, "market-related" strategies that lead market participants as a whole to develop the information and support the overall result may be the best solution.

A social optimum is achieved in our framework when both aggregate output levels and consumption, income, and investment levels for each agent reflect the external effect that each individual has on all others. In principle, the net effect of these externalities could be either excessive unemployment or labor shortages (Malinvaud 1976). ${ }^{10}$ Yet traditional macroeconomic policy has tried to find an aggregate demand policy that will move the economy only to the optimal aggregate output level,--not worrying about sectoral imbalances that are created by the policy. That model was extended to determine optimal aggregate investment and consumption using monetary policy. Yet neither policy acts directly on the individual external effects, and so while an aggregate optimum might be reached, it is very unlikely that the individual agents are at the social optimum.

In addition, the forecasting requirements for aggregate demand policy are daunting. One can see this particularly if one looks from the U.S. to the rest of the world,--East Asia, Latin America, even Euroland, have recently faced serious difficulties in determining the likely future course of the economy. ${ }^{11}$

Monetary policy works through some subsectors of the financial sector, particularly those that borrow from banks and also home-buying. These feed strongly into construction, and in the U.S., to smaller businesses. This is an effect on output. Any effect on the price level requires that some sectors' demand fall enough to bring about a significant overall decline in demand. Figure 3 illustrates how indirect and costly this approach is.

Monetary policy is now typically made by an "independent central bank". This can isolate the decisionmakers from special-interest groups. But giving discretion to unelected experts has serious weaknesses as well. If a pure price-level rule were socially optimal and could be carried out using technical means, the political problem could be solved. New Zealand has followed this approach, and the European Central Bank is attempting a similar policy.

Fiscal policy forces the government to make up the entire externality; in terms of the market to internalize externalities, it implicitly imposes a high price for the government and a zero price for the private sector. In a democratic country, taxes and expenditures are determined by the legislature, and this process typically takes months (in the U.S., normally a year from the OMB budget review in December to the budget passage in October or November). Special interests tend to dominate, and often a "roving bandit" will claim a huge benefit based on special pleading and a sudden political effort (as with agriculture in 2002 in the U.S.) Spending policy

\footnotetext{
${ }^{10}$ In more fully specified macroeconomic environments, where there are job search costs (Pissarides 1990), disutility of labor, and reasons for other resources to be unemployed, the individual choices are even more important. The same would be true if credit market externalities were considered.

${ }^{11}$ Bernanke et al. (1999) and Bernanke and Gertler (1999) propose that monetary policy focus only on inflation, giving up a concern both for output levels and the long-run price level. In contrast, Svensson (1999) broadly favors keeping the price level constant, as a more "fundamental" approach.
} 
always hits some sectors strongly and others weakly, in the effort to affect the whole economy. Tax policy typically does so as well. In general, monetary and fiscal policies affect some sectors of the economy strongly and others weakly, so they cannot mimic the uniform incentive effect that is appropriate to correct for macroeconomic externalities. Also, monetary and fiscal policy affect some parts of the economy more quickly than others, creating a new, intertemporal externality. Finally, neither fiscal nor monetary policy deals with both the nominal demand and the price-level externality, and solving one can make the other worse. Again, see Figure 3.

Other policies can potentially achieve the optimal result both in the aggregate and for individuals. We can put these in our general framework.

There are four general ways to internalize the externality:

1. Change the institutional setting (the game) within which individuals interact;

2. Create a market in the interaction so that individuals internalize the externality in their market decisions;

3. Tax or subsidize the interaction so that the outcome mirrors the market result;

Have the government act to offset the externality. Each of these methods describes a type of policy solution to macroeconomic externality problems.

(1) The government could create the market in consumption or output rights described above. If the government establishes the optimal level of aggregate consumption, the price of these rights will equal the externality. (2) Or, individuals might be able to choose the optimal level directly, through a demand-revealing mechanism for the public good. ${ }^{12}$

(3) Tax incentives can attain the optimal outcome if the government knows individuals' utility functions. It can design a tax on savings (or consumption) that will assure the optimal output level. If the tax can be adjusted to individual demands, the government could impose the optimal externality incentive on each individual. Of course, if the size of the externality tends to fluctuate, the tax would have to fluctuate as well. ${ }^{13}$ (4) A regulatory approach could have the government specify a consumption level for each individual and an investment level for each firm. Keynes' suggestion of government control of investment and French indicative planning were along these lines. However, these policies suffer from much greater information needs than a market system; simple rules of thumb would be needed in practice. ${ }^{14,15}$ In addition, they require

\footnotetext{
${ }^{12}$ Romer (1993) proposed a fairly complex incentive structure to internalize externalities among innovating firms, and such a structure could possibly be adapted to investment.

${ }^{13}$ Christiano and Harrison (1999) model a macroeconomic complementarity, and then develop an automatic fiscal stabilization policy to "internalize the externality".

${ }^{14}$ Many countries have adopted such policies, however; French postwar indicative planning is an example, and some of the East Asian miracle countries (Korea and Taiwan, in particular) controlled and directed investment and consumption. Miller (1995) has argued that these policies would have been desirable in the Eastern European transition countries, in reducing the collapse of demand after 1989.

${ }^{15}$ The alert reader will look for "creating new institutions"; clearly, markets in externalities are an example of that.
} 
some method that assures that the government or an agency would actually choose the public good, rather than a policy helping the agency or its political pressure groups.

It is essential to identify the aggregate demand externality to determine the most desirable policy. Only then can one see whether the chosen policy properly internalizes external effects and attains the optimal outcome, on both the aggregate and disaggregated level. Traditional macroeconomic policies, being directed toward attaining aggregate goals, tend to create distorted individual effects.

Anti-inflation policy fits in the same mold. Traditional policy has focused on aggregate price level outcomes. Relative price effects have been largely ignored and policies have been implemented with little attention to sectoral effects. One could, however, create a market in changing prices (MAP), use taxes and subsidies to provide incentives to reduce inflation (TIP), or change the institutional framework (administrative incomes policies).

When the economy is viewed in a more dynamic context, one concern is whether policy interventions are destabilizing. A policy of government compensation for shocks requires recognizing a shock quickly, plus the political ability to respond appropriately. The monetarist view is that since an optimal policy requires policymakers to continually respond optimally to dynamic disturbances, optimal policy is impossible. However, if the economy is more stable under an optimal policy, policymakers may be able to follow a simple, stable rule. Our impression, viewing macroeconomic fluctuations and financial crises around the world, is that sources of fluctuations tend to vary unpredictably, so that "each source of fluctuation is different" (Caprio and Klingabiel 1997). This suggests making institutional frameworks as stable as possible, and then tying down aggregate price and output levels so that the unpredictable shocks or unpredictable fluctuations cannot push these aggregates far from their long-run equilibrium values. We describe these issues in a simple framework in Table 1. In this table, we focus on four policies, including the "automatic fiscal policy" proposal made by Seidman, following earlier ideas of Abba Lerner (Economist 19 January 2002, p. 64; Seidman 2001). We estimate the size of the various losses from the use of the policy---(specific groups that are harmed from the successful use of the policy, and groups that are harmed when the policy fails).

Each policy alternative has real administrative costs; these costs--plus the costs of deviating from optimal outcomes--determine the best policy. (No policy at all might be best in some cases!). Taxes and subsidies require definition and enforcement just as markets do; their use to achieve policy objectives raises political and administrative questions about the use of the tax system for non-revenue purposes. Can the tax system do both its tax-raising and incentive job and also carry out fiscal policy or an incomes policy?

Markets in externalities require institutions to run them; the strategic interaction must be defined in a legally and politically acceptable manner and the property rights upon which the laws are based must be enforced. U.S. Policymakers have become convinced that the

We would also suggest institutions that would reduce externalities in such areas as financial bubbles, developing more stable forms of banking and of asset holdings, and in a more prosaic fashion, for most countries, reducing monopoly power and local price instability by freeing up international trade. 
administrative costs of programs like such as wage-price controls are very high. ${ }^{16}$ We point out however, that countries with value-added taxes already have the basic institutional framework in place, including both definitions of the value-added rights used by most firms, and a sophisticated "paperwork" trail that moves both among firms and to the government. Thus, these countries would have much lower administrative costs. In addition, new markets in externalities have been developed for air pollution (Joskow et al. 1998, Schmalensee et al. 1998) and these markets have been successful. Yet they (ambiguous wording) defined new and rather intangible property rights, and required that government monitor emissions at many disparate locations. Thus, monitoring changes in value added, or perhaps even prices and quantities, might not be extraordinarily difficult.

We also would like to note the distinction between adjustment to numerous small shocks that have a similar nature, and adjustment to a variety of possibly large and idiosyncratic shocks. Policy rules are typically aimed at the "typical small shock" while it may be the truly large novel shock that does the most damage. A policy to "expect the unexpected" is hard to develop, but this is a useful goal.

For any policy there is a trade-off between administration costs and effective implementation. In general, it is not optimal to design policies that are first best, given many margins that require costly administration. ${ }^{17}$

The difference between New Keynesian and New Classical policy views can be seen as differences in views about these costs. Keynesians regard excessive unemployment as extremely costly--more than proportional to the loss of jobs. This is consistent with models in which workers want, but cannot find, work. In Akerlof and Yellen's (1985) terms, while the external effects for the firms are second-order, the workers who lose their jobs suffer first-order losses. Real business cycle modelers, to the contrary, have seen unemployment as search activity, with excessive unemployment a merely second order effect. That is, workers should be essentially indifferent between working and unemployment---(errors are all at the margin)--and it is only the curvature of the utility hill that causes losses. ${ }^{18}$

In addition, Keynesians have thought that governments can carry out nearly optimal "activist" fiscal and monetary policies at reasonable administrative cost, while the monetarist and New Classical approaches have emphasized both the government's inability to determine optimal policy, and the political constraints on carrying it out. Yet the success of moderate activism under Fed Chairmen Volcker and Greenspan may have moderated these differences.

We feel that a focus on relatively "automatic" market-based policies does reduce the opportunities for rent-seeking. A focus on optimal policies that ignores the probability that special-interest groups will take advantage of policymaking is naive. Fiscal policy in the U.S.

\footnotetext{
${ }^{16}$ Costs of incentive-based policies are discussed in detail in Colander, ed. (1986).

${ }^{17}$ Sah (1987, p. 75) discusses ways of including administrative costs in optimal incentive schemes.

${ }^{18}$ Lucas (1987:27) sees the only gains from optimal policy to be assuring a "perfectly smooth consumption path," not an increase in consumption. The value of this gain is small;--"less than one tenth of a percentage point." In contrast, Okun (1981) calculates that the costs of unemployment are nearly proportional to the percentage loss of GNP below full-employment GNP. For 1976-1985, Gordon (1987) calculates this gap to average 3.6\% of fullemployment GNP.
} 
has traditionally been captured by such rent-seeking groups, while both monetary and fiscal policies in less-developed countries around the world have been captured by special interest groups. When a crisis develops, often "roving bandits" can see a way to manipulate it to make quick gains, as seen in the numerous groups demanding tax cuts or spending increases in 2001-2 in the U.S.

Can fiscal policy be made "automatic" with a structure that assures that taxing and spending change with economic conditions, in a way that does not require new laws to be passed? The answer should be "yes", but for a country like the U.S., with a complex tax system, the specific mechanism is not clear. Countries with a Value-Added Tax may be in a better position to change taxes. For spending, the issue is more difficult, since changes in the appropriation of money for specific projects is hard to make "automatic".

By structuring the macro policy debate within this externality framework, assessing these costs becomes fundamental to choosing appropriate policy. The issues separating economists are then empirical, not theoretical. It is in the assessment of these costs that policy differences really are based. Since macro researchers all accept the same modeling approach, it is surprising how little analysis has gone into this debate. New Classicals still fall into the old Chicago approach to externalities ("In theory they might exist, but in practice I have yet to find one"). New Keynesians minimize the costs of internalizing the externality. Theoretical and empirical research on these questions would seem to be an appropriate route for researchers to take, replacing the current casual assertions. For example, computable general equilibrium models and the current generation of fully specified "real business cycle” models with frictions allow researchers to calculate the economy's response to shocks and so measure, in principle, the specific benefits of a variety of policies that can be incorporated into these models. The shocks facing an economy would also have to be described. The goal of this paper has been to lay out a framework for considering the different policies and their costs and incentive problems, in terms of a broadly acceptable macroeconomic model with microeconomic foundations.

\section{Conclusion: The Real Policy Debate}

Differences in macroeconomic policy conclusions, no longer stem from basic theoretical differences as to whether external effects might exist in macroeconomies, since all major streams of research allow for externalities. Rather they come from differences in assessing their size and nature, and the implementation and political incentive problems and administrative costs of effective policy solutions. The question is whether the admitted incomplete markets can be made "complete" by government policy. Thus the debate can be joined directly taking the agreed-upon theoretical foundations, identifying the incomplete markets and determining the costs of these "market failures," and then examining the effectiveness and costs of potential policy solutions.

We argue that it is central to the progress of economic analysis to take a fundamental "core theory" approach in analyzing economic problems. The policies that we have described-creating more efficient and incentive-compatible institutions, creating new markets, and internalizing externalities by tax policy--are more fundamental than the traditional ad-hoc policies of monetary and fiscal policy. In thinking of externalities, they learn from the micro-

foundations of macro literature, and in the development of institutions that will work, they learn from Mancur Olson's focus on encompassing interests and market-augmenting government

Comment [COMMENT9]:

Who is the 'they' you are referring to? 
(Olson 1993, 2000). With institutional development, analysis and practice, of the sort Olson's IRIS Center supported, they may also become far more effective. 
Table 1: Minimizing Deviations from Optimal Levels: Aggregate Demand

\begin{tabular}{|l|l|l|l|l|l|l|}
\hline a & $\begin{array}{l}\text { Decision } \\
\text { framework }\end{array}$ & Form of errors & $\begin{array}{l}\text { Who loses from } \\
\text { procedure }\end{array}$ & $\begin{array}{l}\text { Who Loses from } \\
\text { policy errors }\end{array}$ & Size of Errors & $\begin{array}{l}\text { Error Correction } \\
\text { Principle }\end{array}$ \\
\hline Monetary Policy & $\begin{array}{l}\text { Central bank } \\
\text { (independent } \\
\text { discretion) }\end{array}$ & $\begin{array}{l}\text { Forecasts of } \\
\text { macro structure } \\
\text { and political } \\
\text { balance Sources } \\
\text { of macro shocks }\end{array}$ & $\begin{array}{l}\text { Bondholders, } \\
\text { borrowers, } \\
\text { financial markets }\end{array}$ & $\begin{array}{l}\text { (Low GDP: job } \\
\text { losers (Inflation: } \\
\text { creditors... } \\
\text { Exporters } \\
\text { foreign asset } \\
\text { holders }\end{array}$ & $\begin{array}{l}\text { Financial } \\
\text { markets } \\
\text { ultimately } \\
\text { politicians, }\end{array}$ \\
moderate (recent \\
years)
\end{tabular}

Fiscal Policy Government (political decision) $\quad$ Forecasts of macro structure and political balance $\quad$ Taxpayers $\quad$ (Low GDP: job losers large, due Political

macro structure

(and political

balance) and public

to lags

criticism

(High GDP $\rightarrow$ inflation: moderate (makes simplistic

creditors... all agents (recent years) rules)

by making mistakes

$\begin{array}{llccc}\text { Automatic } & \text { Law, statistical } & \text { Error in optimal } & \text { Taxpayers } & \text { same as above small? none: law must } \\ \text { Tax } & \text { agency } & \text { output level } & \text { Public (if taxes } & \text { (current } \\ \text { Adjustment } & & \text { too low) changed } & \text { stabilizers }\end{array}$


work well)

Market in Value Added none specified
Firms make decisions

level: public

$$
\text { constrained }
$$

Firms with poor

Firms that

forecasts
Wrong GDP

(expert agency?)

Public, from wrong

output level
Firms improperly

small?

Comparison to hypothetical optimum: stable economy.

Loss measures: large--1-4\% of GDP, moderate--.25-1\% of GDP, small-- .1-.25\% of GDP, very small--<.1\% of GDP 
Macroeconomic Policy and Olson's Collective Action

David C. Colander*

\section{Kenneth J. Koford**}

Jeffrey B. Miller**

Department of Economics

Middlebury College

Middlebury, VT 05753

\section{**Department of Economics \\ University of Delaware \\ Newark, DE 19716}

Earlier versions were presented at the annual meetings of the Western Economic Association, July 5-8, 2001 and the Eastern Economic Association, March 15-17, 2002.

Comments welcomed.

Revised September 6, 2001

Revised March 29, 2002.

Revised July 14, 2002.

Revised September 10, 2002 


\begin{abstract}
Mancur Olson approached all issues from a microeconomic perspective--looking at incentives and seeing how those incentives played out within an institutional framework. He would ask simple questions, such as "What are the individual incentives?" and "How do these incentives influence the development of institutions and outcomes for the economic system?" With those simple questions he would arrive at often profound answers, as in his early work on collective choice, or his late work on the economics of political structures where he argued that leaders with an "encompassing interest" had an incentive to provide public goods.

In many ways Mancur's approach to economics is in tune with modern work on the micro foundations of macroeconomics. But in other ways his work is beyond it. Specifically, Mancur developed his conception of economic problems with in an institutional environment that captured relevant facts of the one we live in. Thus, his micro foundations were more contextual and less abstract than the microfoundations in much modern macro work. This approach means that macro theory has to be seen in a micro framework that incorporates central issues of the institutional structure. It must take account of the incentives of individuals via group action, and of policymakers to take into account the greater public good. Underlying any collective choice problem was a problem of coordination failure.

The coordination failure approach to macro, shown in the work of Robert Clower, Axel Leijonhufvud, Russell Cooper, Andrew John, and John Haltiwanger, fits Olson's vision most closely.. This paper develops an overall framework for macro policy that integrates coordination failure into a micro-foundations set of macro policies that internalize externalities. We argue that macroeconomic policy should focus on the fundamental principle of internalizing externalities, just as does microeconomic policy. Such policies should also be politically self-enforcing, while reducing the incentives for rent-seeking--that is, internalizing political externalities through policies establishing institutions that allow only encompassing interests.

Specifically, in this paper we develop the concepts of "inflation externality" and "aggregate demand externality" and discuss methods of internalizing them. The direct methods include the creation of markets and the development of externality-internalizing taxes. We argue that the creation of a market in rights to an aggregate demand externality can, in principle, internalize it and lead to a stable macroeconomy that provides the encompassing interest of society. We describe that optimal market, explain how it would internalize the externality, and compare it with alternative methods.
\end{abstract}

The next part of the paper considers a macroeconomic inflation externality, and discusses alternative ways that it might be internalized. The aggregate demand externality can be divided into a real output market and an inflation market. The market for inflation rights is Lerner and Colander’s Market Anti-Inflation Plan.

Finally, we compare the institutions needed to deal with inflation and output fluctuations today--monetary and fiscal policy--with those needed for the market and automatic tax stabilizers. The former are far more subject to "roving bandit" problems, since they request policymakers to undertake actions that help or hurt specific sectors of the economy at a 
particular time. While our work to internalize externalities did not begin with the focus on "encompassing interests," when we saw the institutions needed for these policies, they are general interest policies that do no allow narrow temporary political interests to capture them. We feel that this is very much in the spirit of Mancur's last work on "market-augmenting government" policies to assure the success of encompassing interests.

We conclude the paper by arguing that each policy has efficiency and administrative, and political incentive problems, and that differing views of those costs--not differences over the existence of externalities--should be seen as the heart of the macroeconomic policy debate. 